The Antichrist as a guide to Nietzsche's mature ethical theory

Paul Katsafanas

Draft

To appear in Routledge Philosophy Minds: Nietzsche, ed. Paul Katsafanas

There's one thing that's perfectly obvious about Nietzsche: he's critical of traditional ethics. His books are full of impassioned attacks on traditional values: he argues that modern morality may be the "danger of dangers" (GM Preface 6); he claims to show that traditional morality undermines life, health, and power (A 6; GM Preface 6; KSA 12:2[190]); he tells us that "the whole of our European morality" is on the verge of "collapse" (GS 343); and he warns us that "the deeper one looks, the more our valuations disappear—meaninglessness approaches!” (KSA 11:25[505]).

In passages of this sort, Nietzsche isn't just complaining about the details of particular ethical theories. True, he thinks the traditional types of moral theory - virtue theories, sentimentalist theories, utilitarian theories, Kantian and rationalist theories-are failures. ${ }^{1}$ But his critique is more wide ranging: he thinks that many of the concerns and concepts that play central roles in modern ethical life must be rejected. Thus, it's not just that Kant's argument for the Categorical Imperative fails (nearly everyone can agree with that); it's also that the very aspiration for equal consideration, for the equal dignity of persons, for universalization - all of these aspirations, to which the Categorical Imperative is supposed to give expression, are rejected as well. ${ }^{2}$ Kant and his followers aren't just wrong in the details, Nietzsche thinks, but also in the ideals and assumptions that motivate their theories.

And this isn't an idle intellectual error. The consequences are profoundly damaging. It would be one thing if these erudite errors and misconceptions merely blinded us to the truth. But it's quite another if they systematically undermine the power and flourishing of human life, as Nietzsche suggests: "it is my contention that all the supreme values of mankind [...] are symptomatic of decline, nibilistic values" (A 6; cf. GM Preface). Morality, not just in its details but in its most basic aspirations and assumptions, is harmful. In this sense, Nietzsche thinks all moral philosophers hitherto have been blind to the real problems of ethics.

Every serious reader of Nietzsche agrees that Nietzsche makes these claims (whether he's right, whether he has good arguments for these claims, is another story). But this invites a question: is Nietzsche's ethical project purely negative? Is he a brilliant critic who locates deep problems with

1 For a few examples, see BGE 5, BGE 186, BGE 211, GS 335, and A 11-12. I discuss this in more detail in Katsafanas 2013.

2 Two notable examples are TI IX.37 and BGE 257. 
ethical theory but declines to defend any alternatives to the systems that he rejects? Or does he in fact propose and defend some alternative set of ethical claims? ${ }^{3}$

There's controversy on this point, and for good reason. In most of Nietzsche's texts, it's not entirely clear whether he is offering an ethical theory. Consider a few examples. Human, All too Human and Daybreak are largely critical: they discuss some of the presuppositions of morality, argue that traditional morality harbors internal tensions, and claim that traditional morality is damaging. ${ }^{4}$ These works do contain scattered remarks about the importance of health, flourishing, and power, but one searches in vain both for any systematic reflections on these topics and for any substantive account of why we should care about these things. ${ }^{5}$ The Gay Science devotes more time to the articulation of substantive positive ideals, including principally the ability to affirm the eternal recurrence of one's life and the ability to fashion one's character or actions into some kind of aesthetically appealing whole (see, for example, GS 341 and GS 290). But those ideals seem remote from ethical theory; it would be consistent to reject ethical theory, as it's traditionally understood, while championing eternal recurrence and self-affirmation. So even when Nietzsche puts forth ideals, the grounds for these ideals and the relation they are supposed to bear to traditional ethical theory are often unclear.

But things look very different when we consider Nietzsche's late texts. There we do find not just the assertion of ideals, but also a defense of an ethical theory underwriting those ideals. (To be clear: in suggesting that Nietzsche defends an ethical theory, I am not suggesting that he argues for some foundational principle from which all other ethical claims are derived. What I mean is that Nietzsche articulates an interconnected set of normative and evaluative claims and offers a reasoned defense of them. I'll address this in more detail below.) Although I believe that one could make this point by considering Zarathustra, Beyond Good and Evil, On the Genealogy of Morality, or Twilight of the Idols, the points are most explicit in The Antichrist. In the Antichrist, Nietzsche is completely and unequivocally committed to the idea that certain values are justified and others unjustified. In the second section, we read:

What is good? Everything that heightens the feeling of power in man, the will to power, power itself. What is bad? Everything that is born of weakness. (A 2)

That passage is extremely interesting. It straightforwardly asserts a criterion of evaluation: power. ${ }^{6}$ That criterion is present in other works; for example, GM is replete with appeals to power and life. But here Nietzsche bluntly asserts that power is good. Moreover, as I'll indicate below, the following sections defend and employ this ethical claim. By all appearances, then, the Antichrist articulates and defends Nietzsche's ethical theory.

Oddly, debates about Nietzsche's ethical project often neglect the Antichrist. There are reasons for this. The book has stylistic flaws: it is bombastic, aggressive, full of invective. Much of the bookstarting with its title! — can easily be mistaken as a mere expression of animus against Christianity. For that reason, I think, it hasn't attracted as much scholarly attention as somewhat calmer, more traditional works like the Genealogy. But, as a testament to Nietzsche's late ethical theory, the book is

\footnotetext{
3 Throughout the paper, I use "ethical claims" quite broadly, to mean any set of normative or evaluative claims purporting to specify ways in which human beings (or certain types of human beings) should live.

4 A few examples: HH I.22, I.23, I.38; WS 45, 189, 212; D 9, 10, 18, 24, 34, 103, 109-132, 134-137, 210.

5 For claims about health, flourishing, and power, see D 19, 65, 106, 199, 245, 262, 271, 303, 356, and 360.

${ }^{6}$ Or feeling of power, or will to power. For ease of presentation, I elide these distinctions for the moment. I will

examine the connection between them in the next section.
} 
absolutely first rate. If there's one book that encapsulates Nietzsche's ethical project, it's the Antichrist. Here, we find all of the central critical points that Nietzsche wants to make about traditional morality. But we also find explicit articulations of the grounds of his critique, together with a detailed case study of the way in which his theory condemns Christian morality. In short, we find an explicit articulation and defense of Nietzsche's ethical theory. In this essay, I explain how.

The plan of the essay is as follows. Section One provides an overview of The Antichrist as a whole, focusing on the way in which it articulates and employs an ethical theory. Section Two asks whether Nietzsche is attempting to justify the values that he propounds in The Antichrist. There, I argue that Nietzsche does in fact justify his values, but that commentators are often led astray because they assume that Nietzsche rejects the very possibility of justifying values. To see why commentators make this assumption, Section Three articulates seven central tenets of traditional ethical theories. Section Four explains that Nietzsche rejects each of these seven tenets. However, Sections Five through Seven argue that the rejection of these tenets is compatible with the defense of a different kind of ethical theory. In particular, I suggest that Nietzsche justifies power as having a privileged normative status by linking power to facts about the nature of human agency.

\section{The structure of The Antichrist}

Nietzsche opens the Antichrist by condemning the "man of today," who adopts "lazy peace" and "cowardly compromise" (A 1). Rejecting this, Nietzsche tells us that he has discovered a new and distinctive conception of happiness: whereas modern happiness constitutes "resignation," Nietzsche's "formula for our happiness" is "a Yes, a No, a straight line, a goal" (A 1). These statements aren't exactly models of clarity. However, they do give the impression that Nietzschean happiness involves actively striving for some determinate goal, whereas modernity values passively abstaining from goals.

The next section makes this conception of happiness somewhat clearer:

What is happiness? The feeling that power is growing, that resistance is overcome. Not contentedness but more power; not peace but war... (A 2)

Again, happiness is defined in terms of active pursuit of some goal. But now we're given more detail: happiness obtains when, in the pursuit of her goal, the agent successfully overcomes resistances or impediments to her goal.

And this establishes a connection between happiness and power. According to an interpretation originally defended by Bernard Reginster (2006), Nietzsche's identifies willing power with the activity of perpetually seeking and overcoming resistance to one's ends. As Reginster puts it, "will to power, in the last analysis, is the will to the very activity of overcoming resistance" (Reginster 2006, 127). Will to power is manifest in the pursuit of goals other than power: an agent wills power by seeking to encounter and overcome resistance in the pursuit of painting, or writing, or driving, or some other substantive end. If we accept this characterization of power, we can say that power "grows" when resistance is successfully overcome. Thus, in the quotation above, Nietzsche is identifying happiness with the feeling attendant upon successful manifestations of will to power. 
Immediately after these claims about happiness, Nietzsche offers an explicit conception of goodness:

What is good? Everything that heightens the feeling of power in man, the will to power, power itself.

What is bad? Everything that is born of weakness. (A 2)

So we're told that the good is to be identified with whatever heightens power, or with the feeling of power, or with will to power. Badness is to be identified with the opposite. I'll return to this point in a moment.

Then, in section three, Nietzsche states his goals: "The problem I thus pose is... what type of man shall be bred, shall be willed, for being higher in value, worthier of life, more certain of a future" (A 3). He tells us that this higher type of person appeared in the past, "but as a fortunate accident, as an exception, never as something willed." Rather, the contrary type has been willed: "the domestic animal, the herd animal, the sick human animal — the Christian." Section 4 makes the same point: modern "mankind does not represent a development towards something better or stronger or higher." Rather, "the European of today is vastly inferior in value to the European of the Renaissance..." (A 4). Human beings have been diminished, ground down to mediocrity.

What's responsible for this diminishment of human beings? Nietzsche's claim is that religions and their associated moralities have this effect:

Christianity should not be beautified and embellished: it has waged deadly war against this higher type of man; it has placed all the basic instincts of this type under the ban... Christianity has sided with all that is weak and base, with all failures; it has made an ideal of whatever contradicts the instinct of strong life to preserve itself; it has corrupted the reason even of those strongest in spirit by teaching men to consider the supreme values of the spirit as something sinful, as something that leads into error-as temptations. (A 5)

Judeo-Christian morality valorizes traits and actions that lead to decline. How so? In the following sections, as well as in other texts, Nietzsche argues that there are at least three ways in which this happens. First, the values proposed by Judeo-Christian morality celebrate weakness and condemn power. For example, "weakness is being lied into something meritorious ... impotence which doesn't retaliate is being turned into 'goodness'; timid baseness is being turned into 'humility'; submission to people one hates is being turned into 'obedience"' (GM 1.14). Second, the JudeoChristian ethic associates negative emotions with manifestations of power and positive emotions with manifestations of weakness: "for too long, man has viewed his natural inclinations with an 'evil eye', so that they finally come to be intertwined with the 'bad conscience' in him" (GM II.24). Third, Judeo-Christian morality employs a conception of agency that enables the weak to see their weakness as chosen, and hence as strength (GM I.13). For reasons of space, I'll pass over the details here, though see Katsafanas (2011) and (2013) for more details. The essential point, for our purposes, is simply that Judeo-Christian morality tempts potentially "strong" individuals to undermine or weaken themselves. In short, Christianity and its associated mores have led to the "corruption of man" (A 6). 
But what is corruption? Again, we get a straightforward answer: "I call an animal, a species, an individual corrupt when it loses its instincts, when it chooses, when it prefers, what is disadvantageous for it" (A 6). And recall the passage that I quoted above: "it is my contention that all the supreme values of mankind [...] are symptomatic of decline, nibilistic values" (A 6).

Nietzsche here defines corruption in terms of what is disadvantageous for us. But how are we to understand the notion of something's being disadvantageous? Again, Nietzsche is explicit: "Life itself is to my mind the instinct for growth, for durability, for an accumulation of forces, for power. where the will to power is lacking there is decline" (A 6, underlining added). That claim is repeated later: "Wherever the will to power declines in any form, there is invariably also a physiological retrogression, decadence" (A 17). The complaint against Judeo-Christian ethics is thus straightforward: it undermines or leads to a decline in will to power.

And so we get Nietzsche's basic complaint about morality: "It is my contention that all the supreme values of mankind lack this will — that the values which are symptomatic of decline, nibilistic values, are lording it under the holiest names" (A 6). His basic objection is that modern morality promotes values that are inimical to or opposed to will to power.

To drive this point home, Nietzsche even offers an example. Section 7 discusses Mitleid or compassion. He claims that there are two problems with compassion. The first problem is that compassion "has a depressing effect: we are deprived of strength when we feel compassion. That loss of strength which suffering as such inflicts on life is still further increased and multiplied by compassion. Compassion makes suffering contagious" (A 7). The second problem is that the reactions produced by compassion are "perilous": they "cross the law of development," for compassion "preserves what is ripe for destruction." "Compassion negates life and renders it more deserving of negation" (A 7). In short, compassion deprives the compassionate individual of power and fosters an objectionable, power-reducing focus on weakness. (No doubt there are a number of potential problems with these arguments. For our purposes, though, what matters is simply that they are meant as illustrations of the way in which modern morality promotes values that undermine power.)

Let's grant, for the sake of argument, that some of our values undermine or conflict with will to power. Now, it would be bad enough if our values accidentally and unbeknownst to us undermined power. But worse, still, would be if we knowingly developed or maintained values that undermine power. And that's just what Nietzsche suggests that "theologians" do. Section 8 presents theologians as distorting the truth (presumably, the truth about valuations such as the positive valuation of pity). Section 9 claims that Nietzsche "wages war" against all traces of the "theologian's instinct". For "whoever has theologians' blood in his veins, sees all things in a distorted and dishonest perspective to begin with... This faulty perspective on all things is elevated into a morality... and no other perspective is conceded any further value..." (A 9). And again 'Wherever the theologians' instinct extends, value judgments have been stood on their heads and the concepts of 'true' and 'false' are of necessity reversed: whatever is most harmful to life is called 'true'; whatever elevates, enhances, affirms, justifies it, and makes it triumphant is called 'false"' (A $9)$.

Who are these theologians? Later, we'll see that St. Paul is presented as paradigmatic. But Nietzsche also has other enemies in mind; Section 10 presents Kant as a theologian, with Section 11 then 
attacking Kant's moral philosophy. These "theologians" know (or at least are in a position to know) that they are promoting problematic values, but they persist nonetheless.

Suppose we accept these claims. If the dominant values systematically undermine will to power, and will to power is the standard of evaluation, then we have reason to reject the dominant values and to adopt new values. In short, we have reason to engage in revaluation. This is why Nietzsche writes, 'We ourselves, we free spirits, are nothing less than a 'revaluation of all values', an incarnate declaration of war and triumph over all the ancient conceptions of 'true' and 'untrue"' (A 13).

Let's pause here and take stock. What's remarkable about the first thirteen sections of the Antichrist is that they encapsulate the central points of Nietzsche's late ethical project. Nietzsche is explicit about all of the following points:

i. Power is the standard of evaluation.

ii. Modern morality is to be rejected because it conflicts with or undermines power.

iii. By conflicting with will to power, modern morality harms us and makes it less likely that higher individuals will emerge.

iv. Theologians, including moral philosophers like Kant, are especially problematic in that they do (or at least should) recognize that modern morality conflicts with power, yet defend modern morality nonetheless.

v. In addition, theologians distort this fact. They promote falsification, distortion, and self-deception.

vi. Nietzsche's project is to combat this by provoking a revaluation of values.

Notice that (i) and (ii) entail that power has a privileged normative status. Ordinarily, when two values conflict, we can decide to reject one, reject the other, or simply accept the conflict. For example, I value both philosophical insight and leisure. The one often conflicts with the other; I can't pursue both simultaneously. But do I abandon one? Do I reject one? Of course not. I simply live with the trade off, sometimes pursuing one and sometimes pursuing the other.

Other values aren't like that. There are some values that rule out competing claims. Consider justice. If I find that my valuation of wealth conflicts with the requirements of justice, I set that value aside. I don't trade a bit of justice for a bit of wealth, embezzling the college funds or slipping the wallets out of my students' backpacks. No, I view those ends as ruled out by my commitment to justice. In this sense, justice has a privileged status with respect to wealth: when the two conflict, I reject wealth in favor of justice.

Nietzsche suggests that power should operate in this fashion. It should rule out any competing values. And not just trivial values, but our most cherished ones. Power, he claims, conflicts with aspirations and values such as compassion, freedom from suffering, equality, democracy, and so forth. $^{7}$ These are very deep commitments for most of us. In telling us to reject them because they conflict with power, Nietzsche is giving power a privileged normative status.

So, claims (i)-(ii) entail that power has a privileged normative status. Claims (iii)-(v) show us what we're supposed to do in light of that fact.

${ }^{7}$ For a few examples, see BGE 203, 225, 229, 2731 GS 338 377; TI IX.37; A 2. For a more extensive discussion, see Katsafanas 2013. 
I see the remainder of the Antichrist as providing evidence for and application of these claims. Consider a few examples. Sections 22-27 investigate the emergence of Christianity, claiming that it appealed to "strong but bungled men" (A 22) yet corrupted and damaged them. As Nietzsche puts it, "Here, dissatisfaction with oneself, suffering from oneself, are not due to an excessive sensitivity and susceptibility to pain... but on the contrary to an overpowering desire to inflict pain and to find an outlet for inner tensions in hostile acts and deeds. Christianity needed barbaric concepts and values to become master over barbarians" (A 22). Christianity "would become master over beasts of prey: its method is to make them sick, enfeeblement is the Christian recipe for taming..." (A 22).

Analogously, Sections 28-42 focus on Jesus and St. Paul, charting the latter's attempt to consolidate power through revaluation: "In Paul was embodied the opposite type to that of the "bringer of glad tidings': the genius in hatred, in the vision of hatred, in the inexorable logic of hatred!"' (A 42). Paul falsifies Jesus' life and "transposed the center of gravity of that whole existence after this existencein the lie of the 'resurrected' Jesus" (A 42). Thus, "in Paul the priest wanted power once more-he could use only concepts, doctrines, and symbols with which one tyrannizes masses and forms herds" (A 42).

Having discussed the emergence of Christianity, as well as the particular roles of Jesus and St Paul, the remainder of the book focuses mainly on the particular ways in which Christian values have undermined power. A few examples:

That we find no God... is not what differentiates us, but that we experience what has been revered as God, not as 'godlike' but as miserable, as absurd, as harmful, not merely as an error but as a crime against life. (A 47)

Christianity needs sickness just as Greek culture needs superabundance of health-to make sick is the true, secret purpose of the whole system of redemptive procedures constructed by the church...The religious man, as the church wants him, is a typical decadent... (A 51)

At the bottom of Christianity is the rancor of the sick, instinct directed against the healthy, against health itself... Once more I recall the inestimable words of Paul: 'The weak things of the world, the foolish things of the world, the base and despised things of the world hath God chosen.' (A 51)

There are additional complaints as well: A 47-50 focus on the way in which Christian morality distorts truth and promotes falsification: "At every step one has to wrestle for truth... That requires greatness of soul: the service of truth is the hardest service...." (A 50). And what's wrong with falsification? As we'd expect for a theorist who gives power a privileged role, truth's value is supposed to be justified in terms of its relation to power:

Freedom from all kinds of convictions, to be able to see freely, is part of strength. (A 54)

The need for faith, for some kind of unconditional Yes and No...is a need born of weakness. The man of faith, the 'believer' of every kind, is necessarily a dependent man-one who cannot posit himself as an end, one who cannot posit any end at all by himself. (A 54) 
As this overview suggests, much of the Antichrist can be read as a case study of revaluation. The early sections (1-13) present the grounds of the revaluation, whereas the middle and late sections conduct the revaluation.

\section{Relying on values and justifying values}

The Antichrist unambiguously presents and employs an ethical theory. So why is Nietzsche so frequently perceived as lacking or as being opposed to a substantial ethical theory? Why do we have commentators claiming that Nietzsche's texts are "booby-trapped" against extraction of theories (Williams 1993; Pippin 2010), or that Nietzsche's ethical claims are ultimately nothing more than expressions of his subjective preferences (Leiter 2002)?

Here, I think, is the best case a skeptic can make: agree that Nietzsche asserts (i)-(vi), but claim that (i) is seen, by Nietzsche, as unjustified. Let me explain.

Claim (i) says that power has a privileged normative status. But does Nietzsche seek to justify this privileging of power? That's the project of ethical theory, after all: the philosophers of whom Nietzsche is critical all seek to provide not just rhetorical promotions of values, not just passionate praise of them, but arguments that show them to be in some way justified. So we can ask two questions: does Nietzsche share this aspiration? And, if so, how does he seek to justify his values?

There's a temptation to answer the first question negatively. This temptation arises precisely because there seem to be no available answers to the second question. Put simply: if Nietzsche were trying to justify certain values, he'd be offering some type of ethical theory. But he seems to reject not just particular ethical theories, but also the assumptions animating the very quest to offer an ethical theory of any type. So there seems to be no way that he could be offering an ethical theory. So, we seem forced to conclude, (i) must be nothing more than an assertion of Nietzsche's personal preferences.

This reasoning is sometimes explicit (e.g., Leiter 2002) and sometimes implicit (e.g., Russell 1945) in readings of Nietzsche. But I want to point to an often-unnoticed assumption in this line of reasoning. It begins with a simple statement of fact:

(The Fact) Nietzsche rejects a set of claims $\mathrm{p}$

Where p contains claims that tend to be accepted by traditional ethical theorists. Then, commentators make an assumption:

(The Assumption) If $\mathrm{x}$ is an ethical theory, then $\mathrm{x}$ is committed to $\mathrm{p}$.

That is, commentators assume that all ethical theories are committed to some set of claims p. And not just contingently: they assume that anything that counts as an ethical theory will be committed to these claims. It follows from these claims that:

(The Conclusion) Nietzsche rejects all ethical theories. 
So, if we accept the Fact and the Assumption, we get a powerful conclusion. But should we accept the Assumption?

First, let's clarify things. The more substantive we make p, the less plausible it is that the assumption is true. For example, Leiter claims that "any particular morality will... be the object of Nietzsche's critique... only if it" presupposes three descriptive claims about human agency or embraces norms that harm the highest individuals while benefiting the lowest (Leiter 2002, 78). Among these descriptive claims are that "human agents possess a will capable of free and autonomous choice" and that "the self is sufficiently transparent that agent's actions can be distinguished on the basis of their respective motives" (Leiter 2002, 80). But it's astonishing that Leiter thinks this account is adequate. Two of Nietzsche's targets, repeatedly criticized for defending problematic ethical theories, are Schopenhauer and Kant. Yet Schopenhauer denies the first claim and Kant denies the second. ${ }^{8}$ By Leiter's standards, Nietzsche's central targets should escape his critique! (Leiter can try to avoid this problem by claiming that Nietzsche is not attacking the descriptive components of Kant's and Schopenhauer's theories, but merely the normative claims that they make. But this has little plausibility; it's certainly true that Nietzsche objects to Kant's and Schopenhauer's normative claims, but he does so, at least in part, because he rejects their descriptive claims about human agency.)

I mention Leiter's error only because it is a particularly glaring example of a broader problem within Nietzsche scholarship. Whether Nietzsche rejects all ethical theorizing depends on what ethical theory $i$ s. So there's a danger that our preconceptions about what ethical theory is will shape our judgments about whether Nietzsche can have an ethical theory. Leiter, for example, is imagining that ethical theorists posit agents with libertarian freedom self-consciously assessing their utterly transparent mental states. The fact that virtually no actual moral philosopher accepts that view should be an indication that something has gone wrong. (There is a sophomoric reading of Kant that presents him as endorsing this view of agency, but it is demonstrably false. And even if it were true, what would be the interest of showing that Nietzsche rejects some obviously mistaken theory?)

\footnotetext{
8 Here's Schopenhauer on freedom: "By means of his capacity for thought the human being can make present to himself the motives whose influence on his will he senses, in any order he likes, in alternation and repeatedly, to hold them before his will, which is called reflecting: he is able to deliberate, and because of this ability has a much greater choice than is possible for an animal. .... [but] only a very superficial viewpoint can take that relative and comparative freedom for an absolute freedom, a liberum arbitrium indifferentiae. The capacity for deliberation that arises through that freedom in fact produces nothing other than the frequently troubling conflict of motives, over which indecision presides, and whose battle ground is the entire mind and consciousness of the human being. For he repeatedly allows the motives to try their force upon his will in competition with one another, whereby the will gets into the same state that a body is in when different forces work in different directions — until finally the decidedly strongest motive beats the others off the field and determines the will, an outcome that is called a resolve, and that occurs with full necessity as the result of the conflict" (Prize Essay on Freedom of the Will, 57-8). Schopenhauer does complicate this picture by claiming that, in an atemporal act of willing, we somehow choose our own character. But, setting that aside, it's clear that he rejects freedom of the will as traditionally understood. And now for Kant on self-knowledge: "the depths of the human heart are unfathomable" (Metaphysics of Morals 6:447); "it is absolutely impossible by means of experience to make out with complete certainty a single case in which the aim of an action otherwise in conformity with duty rested simply in moral grounds" (Groundwork 4:407). Or, again, "the field of sensuous intuitions and sensations of which we are not conscious, even though we can undoubtedly conclude that we have them, that is obscure representations in the human being (and also in animals) is immense. Clear representations, on the other hand, contain only infinitely few points of this field which lie open to consciousness; so that as it were only a few places on the vast map of our mind are illuminated" (Anthropology 7:135).
} 
As these remarks indicate, we need to do a better job articulating the central commitments of ethical theory. Until we do that, we can't determine whether Nietzsche accepts or rejects ethical theory as such.

\section{The central commitments of Enlightenment ethical theory}

Particular ethical theories diverge tremendously in the details; there's a world of difference between Kant and Hume. But many ethical theories - in particular, the Enlightenment theories spanning roughly the period from Hobbes to Hegel—do share several features:

\section{Justificatory project}

Enlightenment ethical theories treat values as acceptable only if they can be rationally justified. The structure of rational justification is different in different theories. Kant thinks that any acceptable justification will be a priori, whereas the sentimentalists are content with a posteriori justifications. Social contract theorists think that showing that certain claims would be accepted by self-interested agents in hypothetical situations is sufficient to justify these claims, whereas rational intuitionists think we must instead divine these claims by limning the structure of moral reality. So there's deep disagreement about what counts as rational justification. Nonetheless, enlightenment philosophers argue that any claim that cannot be rationally justified must be abandoned: as Hume puts it, "if we take in our hands any volume; of divinity or school metaphysics, for example; let us ask, Does it contain any abstract reasoning concerning quality or number? No. Does it contain any experiential reasoning concerning matter of fact or existence? No. Commit it then to the flames: for it can contain nothing but sophistry and illusion” (Hume 1748/2012: Section XII, Part 3).

\section{Systematicity}

Although they often fail to meet this ideal, Enlightenment ethical theorists strive for clear, precise definitions of central terms, perspicuous arguments, and systematic, internally consistent sets of claims. They have differing degrees of success: no one would award Hegel or Kant any prizes for clarity. But they don't make haphazard, unrelated claims. They aspire to articulate internally consistent theories, the parts of which are mutually reinforcing.

\section{Agreement on central values}

Enlightenment ethical theories converge on a central set of values including equality, dignity, freedom, compassion, happiness, and altruism. They give these values different priority rankings and justify them in different ways, but almost all Enlightenment ethical theorists agree that they are central. These are the values that ethical theory aspires to justify. Failure to do so would render the theory spurious, rather than dislodge the value.

\footnotetext{
${ }^{9}$ For example, Kant claims that he is offering "a pure moral philosophy, completely cleansed of everything that may be only empirical" (Groundwork 4:389).
} 


\section{Conservativism}

As the above remarks indicate, the Enlightenment theorists assume that non-religious ethics can justify something like ordinary Judeo-Christian values. That is, they assume that moral theory will leave most values in place. Thus, a glance through the Metaphysics of Morals shows that Kant takes his moral theory to justify traditional Prussian values, ranging from trivia such as prohibitions on masturbation (worse than suicide, Kant tells us) to restrictions on homosexuality (see 6:425 and 6:277, respectively). Others philosophers, like Bentham and Mill, argue that various institutions must be reformed in order to realize our ideals, but see these ideals as already implicit in our aspirations. As Bentham confidently asserts, everyone accepts utilitarianism: "Not that there is or ever has been that human creature at breathing, however stupid or perverse, who has not on many, perhaps on most occasions of his life, deferred to [the principle of utility]" (Bentham 1789/2007, Section XII).

\section{Universal scope of ethical principles}

Enlightenment ethical theories also aspire to universalism. Universalism comes in different forms, but the type that is relevant for our purposes is the claim that ethical claims have universal scope (see O’Neill 1998 for a helpful analysis). If murder is wrong or compassion is good, this is supposed to be so for everyone. St. Paul claims that "there is neither Jew nor Greek, there is neither bond nor free, there is neither male nor female: for ye are all one in Christ Jesus' (Galatians 3:28). Kant of course agrees: morality is binding not just on all human beings, but on all rational agents. Sentimentalists tend to restrict their claims to some extent: Hume, for example, argues that our judgment that certain acts are morally good is based on our approval of the motives or character traits that generate these acts (see, for example, Hume 1738/2000, Section 3.2.1.7). If human beings displayed widespread variation in the sentiments underwriting these judgments, some form of relativism might be true; but, Hume maintains, "It is universally acknowledged that there is a great uniformity among the actions of men, in all nations and ages, and that human nature remains still the same, in its principles and operations....Mankind are so much the same, in all times and places, that history informs us of nothing new or strange in this particular" (Hume 1748/2012: Chapter 8, Part 1).

The universalism can be understood parametrically: the moral claim applies to anyone who manifests a set of relevant features. What matters, then, is how broadly the parameter is instantiated. Kant's parameter is "rational agency": if you're a rational agent, the moral claim applies to you. Bentham's is broader: if you experience pleasure and pain, the moral claim applies to you. Hume's parameter is more restricted: if you're a human being, the moral claim applies to you. But all of the central Enlightenment theorists aspire for at least a limited form of universality. ${ }^{10}$

\section{Agency and moral motivation}

\footnotetext{
${ }_{10}$ Although Enlightenment theorists purport to offer universalist theories, many philosophers did, in fact, want to draw distinctions between the ethical claims appropriate to Europeans and the colonized, or between men and women, and so on.
} 
The point of morality is to influence action. Morality is supposed to have some sort of grip on us, specifying which actions we should perform and which we should reject. This is why morality applies to human beings but not spiders or ants: we are supposed to be capable of grasping moral norms and regulating our conduct accordingly. The Enlightenment moral theories agree that moral motivation is possible. What in particular this means differs across the theories. On the most maximal picture, it requires that we manifest libertarian freedom. For Kant, it requires that we be capable of actuating ourselves on the basis of self-conscious reflection. For Hume, it requires only that, among our motives, we find emotions of sympathy or benevolence.

\section{Focus on deliberative actions}

Relatedly, Enlightenment theorists take the central object of moral concern to be deliberative actions. The project of ethics is to find and justify principles that govern the selection of individual actions within deliberation. This can include the selection of individual maxims, as in Kant; or the collective deliberation on social institutions, as in Bentham and Mill.

So we have seven core features of Enlightenment moral theory. Other features might be added to this list, but I think these seven are sufficient for our purposes.

\section{Nietzsche's rejection of the seven central commitments of Enlightenment ethical theory}

What makes readers think that Nietzsche can't have an ethical theory? Well, he seems to reject each of the above claims. Let me explain.

\section{1'. Rejection of standard justificatory strategies:}

Nietzsche rejects the standard justificatory strategies, including foundationalism, rational intuitionism, appeals to reflective equilibrium, and appeals to social contracts. ${ }^{11}$ He claims that moral philosophers "make one laugh" with their quest for "a rational foundation for morality." He claims that "seen clearly in the light of day," their theories amount to nothing more than a "scholarly form of good faith in the dominant morality, a new way of expressing it" (BGE 186). When assessing and defending values, Nietzsche spends more time examining their social histories and effects than questions about their justifications (witness GM).

\section{2'. Lack of Systematicity:}

Stylistically, Nietzsche rarely presents clear and explicit defenses of his central concepts and arguments. His writings are mostly critical. While he endorses certain ethical claims, he rarely offers arguments or worked-out proofs for these claims. Nor does he offer clear definitions or analyses of his central positive notions, such as will to power. Some of his claims seem mutually contradictory, to the extent that readers including Robert Pippin and Bernard Williams present his texts as "booby trapped" against articulation of philosophical theory.

\footnotetext{
${ }^{11}$ For discussion of this point, see Katsafanas (2013).
} 


\section{3'. Disagreement on central values:}

Nietzsche rejects values that are central to many Enlightenment ethical theories, such as equality, human dignity, and compassion. Consider a few illustrations. He rejects justice: "We simply do not consider it desirable that a realm of justice and harmony should be established on earth" (GS 377). He rejects equality: "'Equality', a certain factual growing-similar which merely brings itself to expression in the theory of 'equal rights', belongs essentially to decline" (TI IX.37). He rejects egalitarian institutions: "Every enhancement of the type 'man' has so far been the work of an aristocratic society ... that believes in the long ladder of an order of rank and differences in value between man and man" (BGE 257). He rejects the project of minimizing suffering: "You want, if possible - and there is no more insane 'if possible'_to abolish suffering. And we? It really seems that we would rather have it higher and worse than ever... The discipline of suffering, of great suffering-do you not know that only this discipline has created all enhancements of man so far?" (BGE 225). And one could go on and on.

\section{4'. Rejection of conservatism:}

Nietzsche claims that with the death of God, morality is at risk of collapse (see, for example, GS 125 and GS 343). He is skeptical about the possibility of a secular ethic. He utterly rejects the claim that secular ethics can rationally vindicate enlightenment morality. Critical reflection on our values destabilizes them, rather than justifying them: "The deeper one looks, the more our valuations disappear-meaninglessness approaches!" (KSA 11:25[505]). Thus, we are "on the point of tipping over into nihilism — into the belief in absolute valuelessness, that is, meaninglessness" (KSA 13: 7[54]).

\section{Anti-universalism:}

Nietzsche vehemently rejects universalism and endorses pluralism. Consider his discussion of the Laws of Manu in The Antichrist 56-57: Nietzsche praises this system for dividing human beings into different castes and maintaining that different ethical claims apply to different castes. These passages are illustrative: Nietzsche thinks that an appropriate ethical system will draw distinctions between different types of people, assigning different ethical principles to these different types. Elsewhere, he writes, that a "morality that takes itself for unconditional and addresses itself to all does not only sin against taste ... Moralities must be forced to bow first of all before the order of rank; their presumption must be brought home to their conscience-until they finally reach agreement that it is immoral to say: 'what is right for one is fair for the other' " (BGE 221). Analogously, he contends that "what is fair for one cannot by any means for that reason alone also be fair for others ... the demand of one morality for all is detrimental to the higher men; in short ... there is an order of rank between man and man, hence also between morality and morality" (BGE 228). ${ }^{12}$

\section{6'. Rejection of standard pictures of agency}

12 See also D 174; GS 55; BGE 198, 225, 259, 260; GM I.13; A 11; EH IV.4. 
Nietzsche claims that most of our actions are produced unconsciously and driven by inaccessible factors. ${ }^{13}$ Part of what he objects to is the attempt to isolate discrete causes of actions:

Cause and effect: there is probably never such a duality; in truth a continumm faces us, from which we isolate a few pieces, just as we always perceive a movement only as isolated points, i.e. do not really see, but infer... (GS 112, emphasis added)

In addition, he is skeptical about the efficacy of willing

The error of false causality... We believe that we are the cause of our own will...Nor did we doubt that all the antecedents of our willing, its causes, could be found within our own consciousness or in our personal 'motives'... But today... we no longer believe any of this is true. The 'inner world' is full of phantoms and illusions: the will is one of them. The will no longer moves anything, hence does not explain anything-it merely accompanies events; it can even be absent. (TI VI.3)

While Nietzsche clearly does think that self-conscious thought, including thoughts about moral principles, have important impacts on action, he sees these effects as gradual and aggregative. He's very concerned about the long-term impact of moral principles, but less so about the way in which they influence individual acts of individual agents.

\section{7'. Rejection of focus on deliberation}

Nietzsche evinces relatively little interest in examining principles that guide the individual actions of individual agents. He spends far more time examining the broad features of moral systems, which manifest themselves only over long stretches of time. He's interested in the way in which moral theories instantiate themselves in culture, the way in which they gradually undermine certain ways of life while promoting others. Thus, rather than asking whether it's permissible to make a false promise in order to secure cash (Kant, Groundwork 4:421-2), he'll examine the aggregative impact that Judeo-Christian morality has on European culture (GM and elsewhere). Rather than focusing on whether we should strive to act justly, he'll ask whether aspirations for equality and democracy have long-term damaging consequences (TI IX.37, BGE 257; see Katsafanas 2013: Chapter 8 for discussion). In general, his focus is not on the deliberative principles and intentions of individual agents, but instead on the cultural and social effects of widespread values, norms, and moral distinctions.

\section{Does Nietzsche have an ethical theory?}

In sum, Nietzsche rejects seven central constituents of Enlightenment ethical theory. So we're now in a better position to pose our question concerning whether Nietzsche can have an ethical theory. Can a philosopher who rejects 1-7 and maintains 1'-7' have an ethical theory? Or does the commitment to 1'-7' entail that Nietzsche is engaged in a different kind of project, such as mere rhetoric or an attempt at arational persuasion?

\footnotetext{
${ }^{13}$ For discussion of these points, see Katsafanas (2016) and Katsafanas (forthcoming).
} 
I'll argue that 1'-7' are indeed compatible with a certain type of ethical theory. Let me divide this task into three parts. The easy part is showing that 3'-5' are compatible with an ethical theory; I'll show that in this section. A bit harder is showing that 1'-2' and 6'-7' are compatible with an ethical theory; the remaining sections tackle those problems in turn.

3' (the disagreement on central values) and 4' (the rejection of conservativism) are unproblematic. True, Nietzsche champions a distinctive set of values and doesn't think that certain Judeo-Christian values can survive reflective scrutiny. But this obviously doesn't, just by itself, prohibit Nietzsche from having an ethical theory. It just shows that if Nietzsche has an ethical theory, it will be a revisionary one.

An analogous point applies to 5' (the rejection of universalism). Universalism is a widely shared aspiration of Enlightenment ethical theory, but it is not a feature of ethical theory as such. It is arguably absent in much of antiquity. Nothing prevents us from defending a pluralistic ethical theory.

So 3'-5' are perfectly compatible with the defense of an ethical theory. But let's turn to the harder problems.

\section{How Nietzsche justifies the privileged normative status of power}

Consider 1' (the rejection of standard justificatory strategies). If Nietzsche has an ethical theory, he would have to justify it in a distinctive way: he can't appeal to reflective equilibrium, rational intuition, Kantian arguments concerning autonomy, and so on. So what's left?

Elsewhere, I've argued that Nietzsche's ethical theory has the following form:

A. Nietzsche gives will to power a privileged normative status.

B. Nietzsche offers a justification for giving will to power a privileged normative status.

C. Nietzsche justifies will to power's normative status by employing a constitutivist argument. In particular, he argues that

- Each instance of action aims at power

- Power is an inescapable standard of success for action and value

- Thus, power has a privileged normative status. When an action or value generates conflicts with will to power, we have a reason to reject the action or value (not necessarily a decisive reason).

We've seen that (A) is explicit in the Antichrist. So let's move on to the more controversial claims. Regarding (B), I suggest that Nietzsche does in fact provide a justification for his privileging of power. And this justification is provided by $(\mathrm{C})$ : Nietzsche offers a constitutivist defense of power's privileged status. While I can't reconstruct the full argument here, let me mention the three key claims.

First, Nietzsche argues that each instance of human action aims at power. A few exemplary passages:

All "purposes," "goals," "meanings" are only modes of expression and metamorphoses of the single will that is inherent in all events: the will to power. To have purposes, aims, 
intentions, willing in general, is the same thing as willing to be stronger, willing to grow-and, in addition, willing the means to this. (KSA 13:11[96]/WLN 217)

Where there is life is there also will: not will to life but- thus I teach you — will to power. ( $\mathrm{Z}$ II.12)

In these passages, Nietzsche asserts that all action aims at power. ${ }^{14}$ But why believe that? It's certainly not obvious; indeed, there seem to be many counterexamples to the claim. (How am I willing power when I watch television?) Here, as elsewhere, Nietzsche enjoins us to look beyond our superficial reactions to and assumptions about a phenomenon and to uncover its deeper structure. True, it doesn't look like actions are uniformly motivated by an aim of power. But he thinks he can show that they are. (Analogously: it doesn't look like Christian morality promotes decline, or that compassion harms the individual, etc., but Nietzsche thinks deeper examination shows that they do.)

The argument for the claim that all human action aims at power is complex. It hinges on certain claims about the nature of motivation by drives (Triebe); simply put, the will to power thesis is a description of the form that drive-motivated action takes, and Nietzsche thinks that all actions are, at root, motivated by drives. So, if we can establish that all human action is drive-motivated, it will follow that all human action aims at power. The full argument is too complex to reconstruct here; I give it in Katsafanas 2013.

For now, let's just assume that Nietzsche's claim that all human action aims at power is defensible. Our concern is what would follow from this. Suppose we accept a roughly Humean claim concerning the relationship between motivational states and reasons: namely, that aims generate standards of success. More precisely, assume that when I aim at X, I have a prima facie reason for doing what promotes the realization of X. (E.g., if I aim to eat ice cream and Sally doesn't, then I have a prima facie reason to eat ice cream and Sally doesn't have such a reason.) Then, in each instance of action, we'll have prima facie reason to do what promotes the realization of power. And, conversely, we'll have a prima facie reason to avoid what undermines or threatens the realization of power.

If Nietzsche is right that all drive-motivated actions aim at power, and if we can't change the fact that we're motivated by drives, then it will follow that power has a privileged normative status. It is the one aim that we cannot even in principle shed; so it is the one source of reasons that we cannot even in principle shed. So the only way to avoid conflicts with our aiming at power is to eliminate or mitigate other aims that conflict with it. If we find, for example, that valuing compassion somehow undermines power, we'd have reason to reject compassion. If we find that valuing critical inquiry somehow promotes power, we'd have reason to promote critical inquiry. And so on.

\footnotetext{
14 A few more examples: "What man wants, what every smallest part of a living organism wants, is an increase in power" (KSA 13:14[174]/WLN 264). "All driving force is will to power" (KSA 13:14[121]/WLN 256). "Striving is nothing other than striving after power" (KSA 13:14[81]). "Life, as the form of being that is best known to us, is specially a will to the accumulation of force: this is the lever of all the processes of life...Life...: strives for a maximum feeling of power: is essentially a striving for more power: striving is nothing other than striving for power (KSA 13:14[82]/WLN 248; punctuation is Nietzsche's). See also GS 349 and GM III.
} 
Again, the details are complex: each step of the argument requires explanation and defense. I provide this in Katsafanas 2013. Here, I simply want to ask whether the attribution of this kind of ethical theory would be compatible with Nietzsche's commitments.

I've already indicated that claims 3'-5' give us no trouble. What about 1' and 2'? Well, 1' says that Nietzsche rejects standard justificatory strategies, such as moral realism, reflective equilibrium, and so on. No one is going to accuse the will to power theory, as I've reconstructed it, as being just another instance of the standard theories. So 1' presents no difficulties: you could reject every other ethical theory and still think that the drive-based, constitutivist theory succeeds.

But is this compatible with the relatively unsystematic nature of Nietzsche's ethical writings? That is, is it compatible with 2'?

To answer this, let's consider the shape of ethical theory. Here's a common shape for an ethical theory: there are one or more basic values or principles from which all other, more particular values or principles are derived. This basic structure is shared by most ethical theories, including Kantian, utilitarian, and many sentimentalist and social contract theories. Take classical utilitarianism: we're presented with an argument that happiness alone is intrinsically good, pain alone intrinsically bad. We're then given an ethical principle: simply put, an action is morally right iff it maximizes happiness. More particular ethical claims, such as "it would be wrong to steal money from my employer," or "it would be good to donate some money to charity," are justified by showing that they follow from this basic principle. Or consider Kant: he purports to show that we're committed to acting on the Categorical Imperative, which simply tells us to act only on those maxims that we can at the same time will as universal laws. Particular ethical claims, of the sort just mentioned, would be justified by showing that they follow from the Categorical Imperative.

In short, Enlightenment ethical theory tends to start with some foundational value or principle. We then justify particular ethical claims by deriving them from this value or principle.

How are these foundational values or principles themselves justified? It depends on the theory. Kant thinks he can show that the foundational principle, the Categorical Imperative, follows from facts about the nature of rationality or freedom. Utilitarians often appeal to the alleged selfevidence of their foundational judgments. Sentimentalists aspire to show that certain human sentiments are best promoted or realized by commitment to certain principles. Social contract theorists try to show that we'd agree to the foundational principles under certain idealized conditions. And those who propose to justify their claims via reflective equilibrium show that the more basic ethical claims are assessed together with their implications for particular cases, being modified when needed. In each case, the basic claims are taken to have some justification.

Now, as I read Nietzsche there are two major differences between him and these standard theories. First, consider the relation between the basic ethical claim and the more particular ones. Most ethical theories treat this relation as one of derivation or entailment: the basic claim, together with descriptive claims about the agent's situation, entails more particular ethical claims. Nietzsche rejects this. He doesn't appear to derive any more particular claims from his will to power thesis. He doesn't try to show that our commitment to will to power, together with facts about our circumstances, commits us to a unique set of values. Rather, he typically deploys will to power to assess cultures and the sets of values embodied in them. He'll try to show that a whole culture or a whole set of values_or, in some cases, an individual's life_-undermines will to power. Thus, in the Antichrist, we 
have extended discussions of the way in which Christianity and its associated mores undermine will to power. Will to power is here playing a largely negative, critical role: Nietzsche treats it as ruling out certain values. ${ }^{15}$

So Nietzsche isn't using will to power to derive positive content. Instead, he uses it to rule out certain values. Consider an analogy: the instrumental principle. The instrumental principle tells us to take the necessary and available means to our ends. By itself, this doesn't commit us to anything at all. To derive any content from it, you need to have certain ends. But when you do have ends, this requirement rules out certain courses of action and suggests others. What in particular it rules out and recommends depends on the details of your end.

Just so with power: by itself, the injunction will power! doesn't tell us anything. But, when an agent or a culture is committed to various values, engaged in various projects, and undertaking characteristic types of actions, the injunction does rule out certain values and commit us to others.

That's why the will to power thesis allows Nietzsche to assert 5' (the rejection of universalism). The results generated by will to power depend on the values that one antecedently accepts. Presumably, there are many mutually incompatible sets of ethical claims that generate similar degrees of conflict with will to power.

The theory also explains why Nietzsche embraces 3' (the rejection of certain Enlightenment values) and 4' (the rejection of conservatism). Nietzsche thinks he can reveal systematic conflicts between will to power and some of our most cherished values. If this is right, and if power has a privileged normative status, then we have reason to reject these values.

So, if Nietzsche is endorsing this constitutivist account of power's normative status, then it generates some interesting features:

- It does not have a foundationalist structure

- It does not yield a unique set of ethical claims

- It does not issue the standard claims of Enlightenment ethical theory

The constitutivist interpretation explains each of these features. So attributing constitutivism to Nietzsche fits with all of his key theoretical commitments.

\section{Agency and deliberation}

Or does it? I haven't yet considered 6' (Nietzsche's rejection of standard pictures of agency) and 7' (Nietzsche's rejection of the focus on deliberation). Are these commitments compatible with a constitutivist theory?

The objection runs as follows: surely, Nietzsche's theory of agency, with its emphasis on the opacity of human action and the pervasiveness of unconscious motivation, renders him incapable of accepting an ethical theory? In fact, nothing of the sort follows. This is a surprisingly common mistake in the secondary literature on Nietzsche. Put simply, the fact that Nietzsche acknowledges

15 See Katsafanas (2013: Chapters 7-8) for the details. 
opacity and prioritizes unconscious motivation has absolutely no direct bearing on whether he can advocate an ethical theory.

Consider the parallel case for theoretical reason. We know that the vast majority of our beliefs are formed without conscious reflection or deliberation. We know that epistemically irrelevant factors play significant roles in shaping our beliefs: if my desk is cluttered, or if there's a foul smell, I'm more likely to form negative beliefs, for example. We know that many of our beliefs are based on problematic norms: confirmation bias, anchoring, the halo effect, base rate fallacies, and so on. But this doesn't show that epistemic theories are misguided: on the contrary, it shows that they're necessary. The fact that most of our beliefs are formed in these problematic ways shows us why we need epistemic theory. Offering an epistemic theory does not commit one to believing that the theory will correct these processes completely. Uncovering the confirmation bias, for example, doesn't just by itself make us stop exhibiting confirmation bias. But it does give us an opportunity to, in critical situations, reflect on the possibility that confirmation bias is corrupting our belief formation processes. I can step back and ask myself whether I'm exhibiting these errors. Or I can design strategies or policies for counteracting some of these effects. And this can impact my actions.

Just so with ethics. Most of our evaluations are shaped unreflectively. They exhibit manifold tensions, inconsistencies, and distortions. They're shaped by cultural beliefs, religious assumptions, false theories of agency, and so forth. Individual actions, as well as broad swathes of behavior, are influenced by background factors that we fail to notice. But again, this doesn't show that ethical theory is misguided; it shows that ethical theory is necessary. If, like Nietzsche, you think that cultural, religious, and metaphysical assumptions have instilled in us valuations that are deeply misguided, then you'll think shifting these values is crucial. And you'll do that in part by critiquing them. You don't have to imagine that the person who learns that power is normatively authoritative will then go about self-consciously assessing each action for conformity with power. That would be absurdly reflective. But you may envision that person occasionally critiquing some of his central values, determining, for example, that his commitment to democracy or compassion is incompatible with his commitment to power. That realization may not have a great effect on him; even Nietzsche himself, who devotes his life to these sorts of questions, laments their inefficacy in changing his behavior: "One is not always bold, and when one grows tired then one of us, too, is apt to moan 'It is so hard to hurt people-oh, why is it necessary!"” (GS 311). What's needed is a cultural shift as profound as the one that Nietzsche envisions marking the transition from antiquity to modernity: over the course of several hundred years, cultural values shift under the pressure of philosophical argument, artistic glorification, religious conversion, and so on. That kind of shift is what's needed to secure a new set of values. But the fact that this is an aggregative process, the fact that conscious reflection doesn't produce immediate change, does not entail that conscious reflection doesn't produce gradual change. That ethical theory doesn't have immediate, decisive effects doesn't entail that it has no effects whatsoever.

In short: moving from the idea that Nietzsche advocates a complex account of human motivation to the idea that he rejects ethical theory is analogous to moving from the claim that human cognition exhibits various biases and failures to the idea that we shouldn't engage in epistemology.

But what about 7' (the de-emphasis on deliberation)? In fact, 7' is not only compatible with the constitutivist interpretation of Nietzsche's theory, but is entailed by it. Although Nietzsche shows 
little interest in assessing the principles governing individual actions, he is interested in broader questions about the way in which valuations and moral distinctions impact and instantiate themselves in social and cultural arrangements. His project is to diagnose social and cultural illnesses, pathologies, and failures, especially when these are brought about by moralities. Although this distinguishes him from most Enlightenment ethical theorists, it does not prevent him from having an ethical theory. It's just that the effects of the ethical theory, the importance of it, lies not in individual actions, but in broader structural features that are fostered by the values.

In sum, then, the ethical theory that Nietzsche explicitly advocates in the Antichrist, which treats power as having a privileged normative status, is compatible with his rejection of Enlightenment ethical theory.

\section{Conclusion}

I've argued that The Antichrist provides an articulation and defense of Nietzsche's mature ethical theory. Nietzsche's ethical theory centers on the idea that power has a privileged normative status. He justifies this claim by linking power to facts about the nature of human agency. The first thirteen sections of The Antichrist explain this ethical theory; the remaining sections apply it. Despite this, commentators often assert that Nietzsche cannot be offering an ethical theory. I've shown that these commentators are sometimes driven by a tacit assumption that all ethical theories must embrace certain central commitments. Nietzsche rejects or modifies each of these commitments. Nonetheless, I've argued that this does not prohibit him from having an ethical theory: it just prohibits him from having an Enlightenment ethical theory. 


\section{Bibliography}

Bentham, Jeremy (1789/2007), An Introduction to the Principles of Morals and Legislation. Mineola, New York: Dover Publications.

Hume, David (1738/2000), A Treatise of Human Nature. New York: Oxford University Press.

--- (1748/2012), An Enquiry Concerning Human Understanding. Mineola, New York: Dover Publications.

Kant, Immanuel. (1785/1998), Groundwork of the Metaphysics of Morals, Mary Gregor (ed.). New York: Cambridge University Press.

--- (1797/1996), The Metaphysics of Morals, Mary Gregor (ed.). New York: Cambridge University Press.

--- (1798/2006), Anthropology from a Pragmatic Point of View, Robert Louden (ed.). New York: Cambridge University Press.

Katsafanas, Paul (2013) Agency and the Foundations of Ethics: Nietzschean Constitutivism. Oxford: Oxford University Press.

--- (2016), The Nietsschean Self: Moral Psychology, Agency, and the Unconscious. Oxford: Oxford University Press.

--- (forthcoming), "Nietzsche's Account of Self-Conscious Agency," in Philosophy of Action from 1500 to the Present Day, edited by Constantine Sandis. Oxford: Oxford University Press, forthcoming.

Leiter, Brian (2002), Routledge Philosophy Guidebook to Nietzsche on Morality. New York: Routledge.

O’Neill, Onora (1998), "Universalism in Ethics," in The Routledge Encyclopedia of Philosophy. New York: Taylor and Francis.

Pippin, Robert (2010), Nietzsche, Psychology, and First Philosophy. Chicago: University of Chicago Press. Russell, Bertrand (1945), A History of Western Philosophy. New York: Simon \& Shuster.

Schopenhauer, Arthur (1839/1999), Prize Essay on Freedom of the Will, E.F.J. Payne (trans.). New York: Cambridge University Press.

Williams, Bernard (1993), "Nietzsche’s Minimalist Moral Psychology,” European Journal of Philosophy 1(1): 4-14. 